\title{
PENGARUH PELATIHAN TERHADAP KINERJA PERAWAT DENGAN MOTIVASI SEBAGAI VARIABEL MODERASI (Studi pada RSUD Dr. Saiful Anwar Malang)
}

\author{
Siti Umi Ernawati \\ RSUD Dr.Saiful Anwar Malang \\ E-mail: erna.bachtiar@yahoo.co.id
}

\begin{abstract}
Research with the title "The Effect of Training on Performance Motivation as a nurse with Variable moderation. The purpose of this study was to determine the effect of training on the performance of nurses in the RSSA, the influence of motivation on the performance of nurses in the RSSA, as well as to determine the influence of motivation, influence the performance of nurse training in the RSSA Malang. Variables mentioned above were analyzed on several theories. Methods of research carried out by statistical tests using SPSS to analyze the effect of training on performance, the influence of motivation on performance, as well as the role of motivation to the influence of training to performance. The results showed that training had a significant influence on the performance of nurses in the RSSA. While the motivation had no effect on performance and not be able to be moderating influence on the performance of nurse training in the RSSA.
\end{abstract}

Keywords: training, motivation, and nurses performance

\section{PENDAHULUAN}

Sumber Daya Manusia (SDM) menempati posisi yang cukup strategis dalam kehidupan suatu organisasi. Dikatakan demikian karena berhasil ataupun gagalnya suatu organisasi dalam mencapai tujuannya, pada analisis terakhir akan tetap ditentukan oleh unsur manusia didalamnya. Oleh karena itu, masalah manusia menjadi faktor yang cukup penting untuk mendapat perhatian lebih dari suatu organisasi. Berbagai kendala yang menjadi penghalang bagi mulusnyajalannya roda organisasi harus dicari terutama pada unsur manusia itu, karena dengan lenyapnya faktor-faktor penghalang yang bersumber pada unsur manusia dalam organisasi, faktor-faktor lainnya akan dengan mudah teratasi, bahkan sangat mungkin akan lenyap dengan sendirinya. (Siagian, 2004).

Rumah Sakit merupakan suatu organisasi atau institusi kesehatan yang bertanggung jawab terhadap penyelenggaraan pelayanan kesehatan mulai dari pelayanan medik dasar maupun spesialistik yang bermutu, efektif, efisien, dapat dipertanggungjawabkan serta berorientasi pada kepuasan pelanggan. Untuk mewujudkan semua itu, rumah sakit harus mampu menyediakan sumber daya yang professional. Salah satu sumber daya yang harus disiapkan agar mampu memberikan pelayanan prima kepada kliennya adalah perawat. Pelayanan keperawatan di Rumah Sakit merupakan faktor penentu bagi mutu pelayanan dan citra rumah sakit di mata masyarakat (Depkes RI, 1999). Salah satu faktor yang mendukung keyakinan di atas ini adalah kenyataan yang dapat dilihat di unit pelayanan kesehatan terutama di ruang rawat inap, di mana tenaga kesehatan yang selama 24 jam harus berada di sisi pasien adalah tenaga perawatan.

Beberapa penelitian terdahulu tentang pelatihan, menunjukkan pengaruh yang signifikan 
terhadap kinerja pegawai. Dengan demikian, maka perlu dicari dan dianalisis faktor-faktor yang mempengaruhi kinerja tenaga perawatan. Menurut pendapat Keith Davis dalam Mangkunegara (2005), bahwa faktor yang mempengaruhi pencapaian kinerja adalah faktor kemampuan (ability) dan faktor motivasi (motivation). Jika memang kegiatan pelatihan sudah dilakukan secara terus menerus dan berkesinambungan, namun belum terbukti mampu mendongkrak kinerja karyawan, maka penulis berasumsi bahwa kemungkinan ada faktor lain yang perlu ditambahkan agar kinerja karyawan meningkat. Merujuk pada pendapat Keith Davis tersebut diatas maka faktor lain yang kemungkinan masih kurang tersebut adalah motivasi.

Seperti halnya yang terjadi di RSUD Dr. Saiful Anwar (RSSA) Malang yang merupakan rumah sakit terbesar di daerah Malang sekaligus juga merupakan salah satu rumah sakit terbesar di Provinsi Jawa Timur. Berbagai cara sudah dilakukan oleh RSSA untuk meningkatkan kinerja perawat, diantaranya adalah dengan memberikan pelatihan untuk perawat secara terus menerus dan berkesinambungan. Namun dirasakan bahwa pelayanan perawatan masih kurang memenuhi dari apa yang diharapkan pelanggan rumah sakit. Hal ini nampak dari data hasil Indeks Kepuasan Masyarakat (IKM) tahun 2011 tercatat bahwa rata-rata IKM dari satuan kerja pelayanan di lingkungan RSSA adalah 77,61. Sedangkan untuk tribulan pertama tahun 2012 ini (bulan januari sampai maret 2012), rata-rata IKM terhadap mutu pelayanan rumah sakit justru turun menjadi 77,33.

Berdasarkan kenyataan-kenyataan yang diuraikan diatas, hal ini dianggap sangat relevan bila dilakukan penelitian mengenai pengaruh pelatihan terhadap kinerja perawat di RSSA dengan satu variabel moderasi yakni motivasi. Tujuan penelitian ini adalah, pertama, untuk menguji pengaruh pelatihan terhadap kinerja perawat di RSSA. Kedua, untuk menguji pengaruh motivasi terhadap kinerja perawat di RSSA. Dan ketiga untuk menguji peranan motivasi terhadap pengaruh pelatihan terhadap kinerja perawat di RSSA.

Hasil penelitian ini diharapkan bisa memberikan kontribusi bagi pengembangan ilmu pengetahuan terutama pada bidang manajemen sumber daya manusia serta memberikan bukti empiris mengenai pengaruh pelatihan terhadap kinerja pegawai dengan motivasi sebagai variabel moderasi. Sedangkan bagi RSSA, hasil penelitian ini dapat dijadikan masukan dalam menentukan program pelatihan yang ideal bagi perawat serta dapat dijadikan masukan dalam menentukan pemberian motivasi yang tepat kepada perawat RSSA.

\section{TINJAUANPUSTAKA}

Hasil penelitian-penelitian yang terdahulu merupakan acuan yang sangat penting sebagai dasar pemikiran dan bahan pertimbangan dalam melakukan suatu penelitian. Musafir (2009) telah melakukan penelitian tentang Pengaruh Pelatihan dan Motivasi terhadap Kinerja Pegawai Pelabuhan Indonesia IV Gorontalo. Dalam penelitiannya tersebut diperoleh hasil bahwa pelatihan dan motivasi memiliki pengaruh positif secara simultan terhadap kinerja pegawai pada kantor Pelabuhan Indonesia IV Gorontalo.

Soetjipto, (2007) telah melakukan penelitian Pengaruh Faktor Pendidikan, Pelatihan, Motivasi, dan Pengalaman Kerja terhadap Kinerja Kepala Desa (Studi pada Kepala Desa di Kecamatan Pakis dan Tumpang Malang). Dalam penelitiannya dapat dibuktikan bahwa pendidikan, pelatihan, motivasi, dan pengalaman kerja, secara bersamasama berpengaruh secara signifikan terhadap kinerja kepala Desa di Kecamatan Pakis dan Tumpang Kabupaten Malang. Variabel pengalaman secara parsial merupakan variabel yang paling dominan terhadap kinerja kepala desa. Dari penelitian-penelitian terdahulu nampak bahwa ada keterkaitan antara pelatihan maupun motivasi dengan kinerja karyawan. Pelatihan dan motivasi kerja terbukti berpengaruh secara signifikan terhadap kinerja karyawan. Menurut Boedihartono (1991), perawat adalah seseorang yang telah menyelesaikan pendidikan formal keperawatan serta diberi kewenangan untuk melaksanakan peran dan fungsinya. Sedangkan keperawatan adalah bagian integral dari pelayanan kesehatan yang merupakan pelayanan esensial dalam meningkatkan harkat hidup individu, keluarga dan masyarakat. 
Berdasarkan Instruksi Presiden RI Nomor 15 Tahun 1974 tentang pokok-pokok pelaksanaan pembinaan pendidikan dan pelatihan, bahwa pelatihan adalah proses belajar mengajar untuk memperoleh dan meningkatkan keterampilan di luar sistem pendidikan yang berlaku, dalam waktu yang singkat, dan dengan metode yang lebih mengutamakan praktek daripada teori. Sedangkan menurut Simamora (2001), pelatihan adalah proses sistematik yang mengubah perilaku para karyawan dalam suatu arah guna meningkatkan tujuan-tujuan organisasional. Hollenback and Wright (2003), menyatakan juga bahwa pelatihan adalah usahausaha terencana dalam menfasilitasi pembelajaran karyawan untuk meningkatkan kompetensi yang sesuai dengan kebutuhan pekerjaan.

Moekijat (1996) berpendapat bahwa ada tiga syarat yang harus dipenuhi dalam kegiatan pelatihan. Ketiga syarat tersebut adalah bahwa pelatihan harus membantu pegawai menambah pengetahuan dalam menjalankan tugasnya; pelatihan harus menimbulkan perubahan kebiasaan bekerja karyawan, sikapnya terhadap pekerjaan, informasi dan pengetahuan yang diterapkan dalam tugas; dan pelatihan harus berhubungan dengan pekerjaan tertentu. Pada penelitian ini, pengukuran pelatihan dilakukan dengan menggunakan tiga indikator yang merupakan pendapat dari Moekijat tersebut diatas. Selanjutnya oleh penulis dikembangkan dalam tujuh item pertanyaan dengan lima poin skala Likert.

Menurut Siagian (2004), motivasi merupakan akibat dari interaksi seseorang dengan situasi tertentu yang dihadapinya. Karena itulah terdapat perbedaan dalam kekuatan motivasi yang ditunjukkan oleh seseorang dalam menghadapi situasi tertentu dibandingkan dengan orang-orang lain yang menghadapi situasi yang sama. Bahkan seseorang akan menunjukkan dorongan tertentu dalam menghadapi situasi yang berbeda dan dalam waktu yang berlainan pula, terlihat pula bahwa motivasi dapat bersumber dari dalam diri seseorang (sering dikenal dengan istilah motivasi internal atau motivasi intrinsik), akan tetapi dapat pula bersumber dari luar diri orang yang bersangkutan yang dikenal dengan istilah motivasi ekstemal atau ekstrinsik.

Tidak sedikit pakar yang telah menulis dan membahas teori tentang motivasi, salah satunya adalah Teori kebutuhan sebagai hirarkhi dengan Abraham H. Sumbangan Maslow mengenai teori motivasi sampai dewasa ini tetap diakui, bukan hanya di kalangan teoritisi, akan tetapi juga di kalangan para praktisi. Keseluruhan teori motivasi yang dikembangkan oleh Maslow berintikan pendapat yang mengatakan bahwa kebutuhan manusia itu dapat diklasifikasikan pada lima hirarkhi kebutuhan. Sebagaimana ditulis oleh Siagian (2004), lima hirarkhi kebutuhan Maslow tersebut adalah satu yakni Kebutuhan fisiologis ialah kebutuhan-kebutuhan pokok manusia seperti sandang, pangan dan perumahan.

Kebutuhan ini dipandang sebagai kebutuhan yang paling mendasar bukan saja karena setiap orang membutuhkannya terus menerus sejak lahir hingga ajalnya, akan tetapi juga karena tanpa pemuasan berbagai kebutuhan tersebut seseorang tidak dapat dikatakan hidup secara normal. Kedua adalah kebutuhan akan keamanan. Kebutuhan keamanan harus dilihat dalam arti luas, tidak hanya dalam arti keamanan fisik akan tetapi juga keamanan yang bersifat psikologis, termasuk perlakuan adil dalam pekerjaan seseorang. Karena pemuasan kebutuhan ini terutama dikaitkan dengan tugas pekerjaan seseorang, maka kebutuhan keamanan itu sangat penting untuk mendapat perhatian. Selanjutnya adalah kebutuhan sosial. Telah umum diterima sebagai kebenaran universal bahwa manusia adalah makhluk sosial. Keempat, kebutuhan "esteem". Salah satu ciri manusia ialah bahwa dia mempunyai harga diri. Karena itu semua orang memerlukan pengakuan atas keberadaan dan statusnya oleh orang lain. Keberadaan dan status seseorang biasanya tercermin pada berbagai lambang yang penggunaannya sering dipandang sebagai hak seseorang, di dalam dan di luar organisasi. Dan yang terakhir adalah kebutuhan untuk aktualisasi diri. Dewasa ini semakin disadari oleh berbagai kalangan yang semakin luas bahwa dalam diri setiap orang terpendam potensi kemampuan yang belum seluruhnya dikembangkan.

Motivasi dalam penelitian ini selain sebagai variabel bebas juga berperan sebagai variabel moderasi. Motivasi dipandang sebagai kekuatan yang mendorong seseorang untuk melakukan tin- 
dakan tertentu atau berperilaku tertentu. Motivasi yang digunakan dalam penelitian ini adalah motivasi ekstrinsik atau motivasi yang bersumber dari luar diri orang yang bersangkutan, yakni berasal dari manajemen rumah sakit. Pengukuran variabel motivasi dilakukan dengan 11 pertanyaan dengan lima poin skala Likert berdasarkan teori motivasi Abraham Maslow.

Definisi kinerja karyawan yang dikemukakan Bambang Kusriyanto dalam Mangkunegara (2005:9) adalah perbandingan hasil yang dicapai dengan peran serta tenaga kerja persatuan waktu (lazimnya per jam). Sedangkan menurut Moenir (1995:75), kinerja adalah sebagai hasil kerja seseorang pada kesatuan waktu atau ukuran tertentu. Menurut Robbins (1996:24) kinerja adalah suatu ukuran yang mencakup keefektifan dan efisiensi dalam pencapaian tujuan dan efisiensi merupakan rasio dari keluaran efektif terhadap masukan yang diperlukan untuk mencapai tujuan.

Kinerja menurut Mangkunegara (2000:67) adalah hasil kerja secara kualitas dan kuantitas yang dicapai oleh seseorang karyawan dalam melaksanakan tugasnya sesuai dengan tanggung jawab yang diberikan kepadanya. Menurut pendapat Keith Davis dalam Mangkunegara (2000:67), bahwa faktor yang mempengaruhi pencapaian kinerja adalah factor kemampuan (ability) dan faktor motivasi (motivation).

Dalam penelitian ini, kinerja perawat dipotret berdasarkan tujuh prinsip etik keperawatan yang merupakan standar ideal kinerja perawat. Menurut Depkes RI Modul I, (2009:8), tujuh prinsip etik keperawatan tersebut adalah: (1). Respek. Respek diartikan sebagai perilaku perawat yang menghormati atau menghargai pasien/klien dan keluarganya. Perawat harus menghargai hak-hak pasien/ klien seperti hak untuk pencegahan bahaya dan mendapatkan penjelasan secara benar. (2). Otonomi. Pada prinsipnya otonomi berkaitan dengan hak seseorang untuk memilih bagi diri mereka sendiri, apa yang menurut pemikiran dan pertimbangannya merupakan hal yang terbaik. (3). Beneficence (kemurahan hati). Kemurahan hati berkaitan dengan kewajiban untuk melakukan hal yang baik dan tidak membahayakan orang lain. (4). Non
Maleficence (tidak mencederai). Prinsip ini berkaitan dengan kewajiban perawat untuk tidak dengan sengaja menimbulkan kerugian atau cidera. (5). Konfidensialitas / Kerahasiaan. Prinsip ini berkaitan dengan penghargaan perawat terhadap semua informasi tentang pasien/klien yang dirawatnya. Pasien/klien harus dapat menerima bahwa informasi yang diberikan kepada tenaga profesional kesehatan akan dihargai dan tidak disampaikan/ diberbagikan kepada pihak lain secara tidak tepat. (6). Keadilan / Justice. Keadilan berkenaan dengan kewajiban untuk berlaku adil kepada semua orang. Azas ini bertujuan untuk melaksanakan keadilan dalam transaksi dan pelayanan/perlakuan antar individu pasien/klien, berarti setiap orang harus mendapatkan perlakuan yang sama sesuai dengan kebutuhannya. (7). Kesetiaan. Kesetiaan berkaitan dengan kewajiban untuk selalu setia pada kesepakatan dan tanggung jawab yang telah dibuat. Setiap tenaga keperawatan mempunyai tanggung jawab asuhan keperawatan kepada individu, pemberi kerja, pemerintah dan masyarakat. Dari prinsip etik keperawatan inilah yang akan dipakai pedoman oleh penulis sebagai indikator kinerja perawat.

Hipotesis penelitian yang dirumuskan dan akan diuji kebenarannya melalui penelitian ini adalah H1: Pelatihan berpengaruh signifikan terhadap kinerja perawat di RSSA, H2: Motivasi berpengaruh signifikan terhadap kinerja perawat di RSSA, H3: Motivasi mampu memoderasi pengaruh pelatihan terhadap kinerja perawat di RSSA.

Berdasarkan hipotesis yang diajukan diatas, maka model hipotesis penelitian ini adalah sebagai berikut:

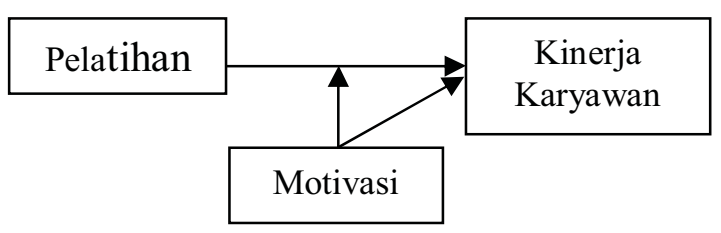

Gambar 1: Model Hipotesis Penelitian

\section{METODE PENELITIAN}

Penelitian ini termasuk kategori penelitian kuantitatif dengan metode survei. Dikatakan demi- 
kian karena dalam mengumpulkan data menggunakan daftar pertanyaan (questionnaire). Sedangkan untuk populasi dalam penelitian ini adalah seluruh perawat di RSUD Dr. Saiful Anwar Malang yang berjumlah 928 orang. Teknik pengambilan sampel dalam penelitian ini adalah teknik purposive sampling, yaitu sampel yang ditentukan berdasarkan kriteria tertentu.

Kriteria yang ditentukan adalah perawat yang sudah pernah mengikuti pelatihan dengan penugasan dari RSSA. Berdasarkan perhitungan besaran sampel menurut Burhan Bungin seperti sudah dikutip dari Radiany, Rahmady HM (2004), maka besaran sampel minimal sebesar 90,3 sampel penelitian. Namun dalam penelitian ini, peneliti akan mengambil 100 sampel.

Instrumen sebagai alat pengumpulan data dalam penelitian ini berupa daftar pernyataan atau kuesioner jenis tertutup yang harus diisi oleh yang dipilih. Kuesioner dimaksudkan untuk menjaring data yang berkaitan dengan variabel pelatihan, motivasi, dan kinerja perawat menggunakan skala Likert, responden diminta mengisi kuesioner dalam jumlah lima kategori. (Singarimbun, 1995) yaitu bobot nilai dalam kisaran 1 hingga 5 .

Variabel dalam penelitian ini ada tiga variabel yang diteliti, yaitu variabel terikat Y (kinerja perawat), sedangkan variabel bebas $X$ yaitu pelatihan dengan simbol $\mathrm{Xl}$ dan motivasi dengan simbol X2, serta variabel moderasi (motivasi) dengan simbol $X_{1} X_{2}$. Dalam memberikan arah yang jelas dalam pengukuran variabel yang ada, maka perlu dijabarkan definisi operasional variabel.

Kinerja Perawat adalah suatu hasil kerja atau ukuran sukses bagi perawat RSSA. Dalam mengukur kinerja perawat digunakan beberapa indikator yang dipakai sesuai dengan prinsip etik keperawatan. Indikator-indikator tersebut adalah kerespekan perawat, keotonomian perawat, kemurahan hati perawat, kemampuan perawat untuk tidak menimbulkan kerugian atau cidera kepada pelanggan dalam menyelesaikan pekerjaan, kemampuan perawat untuk menjaga rahasia pasien/klien yang dirawatnya, kewajiban perawat untuk berlaku adil kepada semua orang, dan kesetiaan perawat terhadap kesepakatan dan tanggung jawab asuhan keperawatan kepada individu, pemberi kerja, pemerintah dan masyarakat.

Pelatihan dalam penelitian ini adalah merupakan kegiatan yang diikuti perawat dalam rangka meningkatkan kemampuan bekerja (pengetahuan dan ketrampilan) dalam bentuk on the job training maupun off the job training. Pelatihan yang dimaksud dapat berupa pelatihan yang diselenggarakan sendiri oleh RSSA maupun pelatihan yang diselenggarakan oleh pihak lain, kemudian RSSA berpartisipasi mengikutkan karyawannya pada pelatihan tersebut. Indikator yang dipakai dalam mengukur pengaruh pelatihan ini sesuai dengan yang dikemukakan Moekijat (1996) yang berpendapat bahwa ada tiga syarat yang harus dipenuhi dalam kegiatan pelatihan. Ketiga syarat tersebut adalah bahwa pelatihan harus membantu pegawai menambah pengetahuan dalam menjalankan tugasnya, pelatihan harus menimbulkan perubahan kebiasaan bekerja karyawan, sikapnya terhadap pekerjaan, informasi dan pengetahuan yang diterapkan dalam tugas serta pelatihan harus berhubungan dengan pekerjaan tertentu.

Motivasi dalam penelitian ini adalah motivasi eksternal atau ekstrinsik. Menurut Sondang P Siagian (2004), motivasi eksternal atau ekstrinsik adalah motivasi yang bersumber dari luar diri orang yang bersangkutan. Dengan demikian motivasi eksternal dalam penelitian ini adalah faktor yang mendorong perawat RSSA untuk melakukan pekerjaannya yang bersumber dari pihak luar diri individu perawat yang dalam hal ini adalah pihak manajemen RSSA. Indikator yang dipakai dalam mengukur pengaruh motivasi dalam penelitian ini dengan mengambil teori motivasi dari Abraham $\mathrm{H}$. Maslow yaitu motivasi untuk memenuhi kebutuhan fisiologis, motivasi untuk mendapatkan rasa aman, motivasi untuk mendapatkan kebutuhan sosial, motivasi untuk mendapatkan reward/penghargaan, dan motivasi untuk beraktualisasi diri.

\section{HASIL PENELITIAN DAN PEMBAHASAN}

Setelah diadakan penelitian langsung dan pengumpulan data sesuai dengan yang diperlukan, 
maka selanjutnya data tersebut diolah agar diketahui dan ditarik kesimpulan guna menjawab hipotesis yang dikemukakan sebelumnya. Berdasarkan kuesioner yang disebar oleh peneliti, maka hasilnya dapat dilihat dalam tabel distribusi frekuensi sebagai berikut:

Pada tersebut nampak bahwa pernyataan atau item pertama $\left(\mathrm{X}_{1} .1\right)$ yakni tentang meningkatnya pengetahuan para perawat tentang bidang pekerjaannya setelah mengikuti pelatihan, hasil ini menunjukkan bahwa kesemua responden (100\%) menyatakan setuju bahwa pelatihan memang bisa meningkatkan pengetahuan. Maka pendapat Moekijat bahwa pelatihan itu mampu meningkatkan pengetahuan dalam menjalankan tugas adalah benar terbukti di RSSA.

Pernyataan atau item kedua $\left(\mathrm{X}_{1} .2\right)$ yakni tentang semakin meningkatnya kompetensi para perawat setelah mengikuti pelatihan, maka hasil ini menunjukkan bahwa mayoritas responden menyatakan bahwa pelatihan memang bisa meningkatkan kompetensi mereka sebagai seorang perawat. Hampir 100\% responden menyatakan setuju bahwa kompetensi mereka semakin meningkat setelah mengikuti pelatihan. Dengan demikian maka pendapat Hollenback bahwa pelatihan merupakan usaha-usaha terencana untuk meningkatkan kompetensi adalah benar terbukti di RSSA.

Pernyataan atau item ketiga $\left(X_{1} .3\right)$ yakni tentang semakin meningkatnya ketrampilan para perawat setelah mengikuti pelatihan, maka hasil ini menunjukkan bahwa mayoritas responden menyatakan bahwa pelatihan memang bisa meningkatkan ketrampilan mereka sebagai seorang perawat. Dengan demikian maka Instruksi Presiden RI bahwa pelatihan itu adalah suatu proses belajar mengajar untuk meningkatkan ketrampilan adalah benar terbukti di RSSA. Pernyataan atau item keempat $\left(\mathrm{X}_{1} .4\right)$ yakni tentang tidak sulitnya menyesuaikan diri terhadap hal-hal baru setelah mengikuti pelatihan, hasil ini menunjukkan bahwa mayoritas responden menyatakan bahwa pelatihan memang bisa membuat para perawat lebih "welcome" terhadap hal-hal baru. Seperti diketahui bersama bahwa perkembangan ilmu pengetahuan maupun teknologi sangat cepat sekali peningkatan perubahannya. Sebagai seorang asisten dokter (tenaga medis) dalam penyelenggaraan pelayanan kesehatan, perawat dituntut untuk bisa cepat menyesuaikan diri dengan hal-hal baru.

Pernyataan atau item kelima $\left(\mathrm{X}_{1} .5\right)$ yakni tentang semakin meningkatnya kemampuan bekerja sama dengan karyawan lain setelah mengikuti pelatihan, hasil ini menunjukkan bahwa mayoritas responden menyatakan bahwa pelatihan memang bisa membuat mereka lebih mampu bekerja sama dengan karyawan lain. Pelatihan juga mampu membentuk peserta menjadi pribadi yang mampu bekerja secara team (kerjasama). Hal ini akan berdampak sangat bagus karena di institusi pelayanan publik seperti halnya di rumah sakit, jenis ketenagaan sangat beragam jika dilihat dari disiplin ilmunya. Jika seorang perawat kurang mampu bekerja sama dengan karyawan lain, tentu akan mengganggu proses pelayanan kesehatan yang diberikannya.

Tabel 1: Tanggapan Responden Tentang Pelatihan $\left(\mathrm{X}_{1}\right)$

\begin{tabular}{ccccccc}
\hline \multirow{2}{*}{ Pernyataan } & \multicolumn{5}{c}{ Skor } & \multirow{2}{*}{ Total } \\
\cline { 2 - 6 } & $\mathbf{5}$ & $\mathbf{4}$ & $\mathbf{3}$ & $\mathbf{2}$ & $\mathbf{1}$ & \\
\hline $1\left(\mathrm{X}_{1} \cdot 1\right)$ & 68 & 32 & 0 & 0 & 0 & 100 \\
$2\left(\mathrm{X}_{1} \cdot 2\right)$ & 37 & 62 & 1 & 0 & 0 & 100 \\
$3\left(\mathrm{X}_{1} \cdot 3\right)$ & 35 & 62 & 3 & 0 & 0 & 100 \\
$4\left(\mathrm{X}_{1} \cdot 4\right)$ & 23 & 62 & 14 & 1 & 0 & 100 \\
$5\left(\mathrm{X}_{1} \cdot 5\right)$ & 29 & 60 & 10 & 1 & 0 & 100 \\
$6\left(\mathrm{X}_{1} \cdot 6\right)$ & 30 & 61 & 8 & 1 & 0 & 100 \\
$7\left(\mathrm{X}_{1} \cdot 7\right)$ & 12 & 76 & 11 & 1 & 0 & 100 \\
\hline
\end{tabular}


Pernyataan atau item keenam $\left(\mathrm{X}_{1} .6\right)$ yakni tentang adanya keterkaitan antara pelatihan dengan pekerjaan keseharian, hasil ini menunjukkan bahwa mayoritas responden menyatakan bahwa pelatihan yang sudah diikuti selama ini sudah ada hubungannya dengan pekerjaaannya sebagai seorang perawat. Dengan demikian maka pendapat Moekijat bahwa pelatihan itu harus berhubungan dengan pekerjaan tertentu sudah dilaksanakan di RSSA.

Pernyataan atau item ketujuh $\left(\mathrm{X}_{1} .7\right)$ yakni tentang pelatihan yang diikuti perawat selama ini sudah sesuai/relevan dengan tugas-tugas maupun we- wenangnya sebagai perawat, maka hasil ini menunjukkan bahwa mayoritas responden menyatakan bahwa pelatihan yang diikuti selama ini sudah terkait dengan tugas, pokok, dan fungsi mereka sebagai perawat. Dan hanya ada 1 orang responden yang menyatakan bahwa pelatihan yang diikutinya sama sekali tidak terkait dengan tupoksinya sebagai perawat. Dengan demikian maka pendapat Moekijat bahwa pelatihan itu harus berhubungan dengan pekerjaan yang diemban oleh pesertanya sudah dilaksanakan di RSSA. Selanjutnya pada table distribusi berikut:

Tabel 2: Tanggapan Responden Tentang Motivasi $\left(\mathrm{X}_{2}\right)$

\begin{tabular}{ccccccc}
\hline \multirow{2}{*}{ Pernyataan } & \multicolumn{5}{c}{ Skor } & Total \\
\cline { 2 - 5 } & $\mathbf{5}$ & $\mathbf{4}$ & $\mathbf{3}$ & $\mathbf{2}$ & $\mathbf{1}$ & \\
\hline $1\left(\mathrm{X}_{2} \cdot 1\right)$ & 11 & 50 & 26 & 10 & 3 & 100 \\
$2\left(\mathrm{X}_{2} \cdot 2\right)$ & 4 & 39 & 30 & 23 & 4 & 100 \\
$3\left(\mathrm{X}_{2} \cdot 3\right)$ & 2 & 41 & 23 & 26 & 8 & 100 \\
$4\left(\mathrm{X}_{2} \cdot 4\right)$ & 6 & 30 & 40 & 17 & 7 & 100 \\
$5\left(\mathrm{X}_{2} \cdot 5\right)$ & 9 & 41 & 31 & 12 & 7 & 100 \\
$6\left(\mathrm{X}_{2} \cdot 6\right)$ & 11 & 50 & 27 & 10 & 2 & 100 \\
$7\left(\mathrm{X}_{2} \cdot 7\right)$ & 4 & 52 & 28 & 13 & 3 & 100 \\
$8\left(\mathrm{X}_{2} \cdot 8\right)$ & 7 & 50 & 29 & 10 & 4 & 100 \\
$9\left(\mathrm{X}_{2} \cdot 9\right)$ & 2 & 37 & 42 & 12 & 7 & 100 \\
$10\left(\mathrm{X}_{2} \cdot 10\right)$ & 5 & 36 & 45 & 8 & 6 & 100 \\
$11\left(\mathrm{X}_{2} \cdot 11\right)$ & 14 & 54 & 23 & 7 & 2 & 100 \\
\hline
\end{tabular}

Pada tabel 2 diatas, nampak bahwa pernyataan atau item pertama $\left(\mathrm{X}_{2} .1\right)$ dari variabel motivasi yakni tentang sudah terpenuhinya gaji sesuai dengan hasil kerja perawat, maka hasil ini menunjukkan bahwa mayoritas atau tepatnya separuh dari responden menyatakan bahwa rumah sakit sudah memenuhi atau memberikan gaji kepada perawat sesuai dengan hasil kerjanya. RSSA adalah institusi publik milik Pemerintah Provinsi Jawa Timur. Jadi untuk persoalan gaji, sudah ada ketentuan dengan jelas besaran gaji yang harus diterimakan kepada karyawannya. Masing-masing perawat dengan status Pegawai Negeri Sipil (PNS), diterimakan gaji sesuai dengan golongan kepangkatannya. Sedangkan tenaga perawat dengan status tenaga kontrak/ honor, diterimakan gaji sesuai dengan tingkat pendidikannya.

Pernyataan atau item kedua $\left(\mathrm{X}_{2} .2\right)$ dari variabel motivasi yakni tentang sudah diberikannya oleh rumah sakit tunjangan untuk perawat sesuai dengan resiko kerja ataupun tunjangan lainnya, maka hasil ini menunjukkan bahwa mayoritas responden menyatakan bahwa rumah sakit relatif cukup memberikan tunjangan untuk perawat sesuai dengan resiko kerja ataupun tunjangan lainnya. Untuk kebutuhan tunjangan ini, memang tidak semua perawat mendapatkan tunjangan sesuai dengan resiko kerjanya. Jika status tenaga perawat tersebut adalah PNS, maka secara otomatis yang bersangkutan mendapatkan tunjangan fungsional 
sebagai perawat dengan segala resiko kerja yang melekat padanya. Namun jika status tenaga perawat tersebut adalah tenaga kontrak/honor, maka tunjangan yang dia peroleh tidak sebesar tenaga perawat dengan status ketenagaan sebagai PNS.

Pernyataan atau item ketiga $\left(\mathrm{X}_{2} .3\right)$ dari variabel motivasi yakni tentang sudah diberikannya oleh rumah sakit fasilitas seragam kerja yang memadai untuk para perawat, maka hasil ini menunjukkan bahwa mayoritas responden menyatakan bahwa rumah sakit sudah cukup memberikan fasilitas seragam kerja yang memadai untuk para perawat. Terkait dengan seragam kerja perawat, memang tenaga perawatan relatif membutuhkan seragam kerja yang lebih dibanding karyawan lainnya. Frekuensi kontak dengan pasien dengan segala permasalahannya kadang membuat para tenaga perawat juga harus kontak dengan darah ataupun kotoran lainnya dari pasien.

Pernyataan atau item keempat $\left(\mathrm{X}_{2} \cdot 4\right)$ dari variabel motivasi yakni tentang sudah diberikannya santunan kecelakaan jika ada perawat yang mengalami kecelakaan kerja, maka hasil ini menunjukkan bahwa mayoritas responden masih ragu-ragu untuk menyatakan bahwa rumah sakit sudah memberikan santunan kecelakaan jika ada perawat yang mengalami kecelakaan kerja. Hal ini berarti bahwa rumah sakit belum memberikan kejelasan kebijakan atau adanya ketidakpastian tentang adanya santunan kecelakaanjika ada perawat yang mengalami kecelakaan kerja.

Pernyataan atau item kelima $\left(\mathrm{X}_{2} .5\right)$ dari variabel motivasi yakni tentang sudah diberikannya jaminan kesehatan baik untuk perawat maupun keluarganya, maka hasil ini menunjukkan bahwa mayoritas responden menyatakan bahwa rumah sakit sudah memberikan jaminan kesehatan baik untuk perawat maupun keluarganya. Hal ini berarti bahwa pihak rumah sakit telah memberikan jaminan kesehatan untuk tenaga perawat yang bekerja di RSSA. Begitu juga dengan keluarga perawat yang juga telah dijamin kesehatannya oleh pihak rumah sakit.

Pernyataan atau item keenam $\left(\mathrm{X}_{2} \cdot 6\right)$ dari variabel motivasi yakni tentang sudah diberikannya dukungan adanya paguyuban perawat agar sesama perawat bisa berinteraksi dengan perawat lainnya, maka hasil ini menunjukkan bahwa mayoritas atau tepatnya separuh dari responden menyatakan bahwa rumah sakit sudah memberikan dukungan adanya paguyuban perawat agar sesama perawat bisa berinteraksi dengan perawat lainnya,. Hal ini berarti bahwa pihak rumah sakit telah memberikan kelonggaran kepada tenaga perawat untuk mengikuti kegiatan paguyuban perawat. Saat ini organisasi atau paguyupan perawat yang mewadahi komunitas para perawat memang sudah terbentuk di RSSA.

Pernyataan atau item ketujuh $\left(\mathrm{X}_{2} .7\right)$ dari variabel motivasi yakni tentang sudah diberikannya waktu istirahat yang cukup bagi para perawat disela-sela pelaksanaan tugas, maka hasil ini menunjukkan bahwa mayoritas responden menyatakan bahwa rumah sakit sudah memberikan waktu istirahat yang cukup bagi para perawat disela-sela pelaksanaan tugas Hal ini berarti bahwa pihak rumah sakit telah memberikan jam istirahat yang dianggap sudah cukup oleh tenaga perawat disela kesibukannya yang harus mendampingi pasien selama 24 jam penuh. Pengaturan jam kerja untuk tenaga perawat dalam 24 jam sehari telah diatur oleh RSSA sebanyak tiga shift.

Pernyataan atau item kedelapan $\left(\mathrm{X}_{2} .8\right)$ dari variabel motivasi yakni tentang sudah dilibatkannya perwakilan perawat dalam setiap pengambilan keputusan, maka hasil ini menunjukkan bahwa mayoritas responden menyatakan bahwa rumah sakit sudah melibatkan perwakilan perawat dalam setiap pengambilan keputusan. Hal ini berarti bahwa pihak rumah sakit telah melibatkan perwakilan perawat dalam setiap pengambilan keputusan. Secara organisatoris, tenaga perawat yang mewakili keperawatan dalam pengambilan keputusan di tingkat RS diwadahi dalam suatu komite yang dinamakan Komite Keperawatan.

Pernyataan atau item kesembilan $\left(\mathrm{X}_{2} .9\right)$ dari variabel motivasi yakni tentang sudah diberikannya penghargaan kepada perawat misalnya kejelasan status sebagai perawat terbaik, maka hasil ini menunjukkan bahwa mayoritas responden masih ragu-ragu untuk menyatakan bahwa rumah sakit sudah memberikan penghargaan kepada perawat 
misalnya kejelasan status sebagai perawat terbaik. Hal ini berarti bahwa pihak rumah sakit belum memberikan kepastian kebijakan untuk diadakannya pemilihan perawat terbaik.

Pernyataan atau item kesepuluh $\left(\mathrm{X}_{2} \cdot 10\right)$ dari variabel motivasi yakni tentang sudah disahkannya simbol-simbol yang digunakan hanya oleh para perawat, maka hasil ini menunjukkan bahwa mayoritas responden masih ragu-ragu untuk menyatakan bahwa rumah sakit sudah mengesahkan simbolsimbol yang digunakan hanya oleh para perawat. Hal ini berarti bahwa pihak rumah sakit belum mengeluarkan suatu keputusan yang mengesahkan tentang simbol-simbol keperawatan. Saat ini masing-masing unit kerja telah mengeluarkan simbol-simbol sendiri untuk tenaga keperawatannya. Namun hal tersebut belum disahkan secara resmi oleh pihak rumah sakit. Padahal semua orang memerlukan pengakuan atas keberadaan dan statusnya oleh orang lain. Keberadaan dan status seseorang biasanya tercermin pada berbagai lambang yang hanya digunakan oleh komunitas tersebut.

Pernyataan atau item ke- $11\left(\mathrm{X}_{2} .11\right)$ dari variabel motivasi yakni tentang sudah diberikannya kesempatan yang terbuka lebar kepada perawat untuk meniti karir yang lebih tinggi, maka hasil ini menunjukkan bahwa mayoritas responden menyatakan bahwa rumah sakit sudah memberikan kesempatan yang terbuka kepada perawat untuk meniti karir yang lebih tinggi. Hal ini berarti bahwa peluang berkarir di RSSA terbuka secara lebar bagi tenaga perawatan. Bahkan di RSSA ada satu bidangyang khusus menangani pengembangan karir para karyawannya yakni Bidang Pengembangan Profesi. Adalah hal yang normal apabila dalam meniti karier, seseorang ingin agar potensinya itu dikembangkan secara sistematik sehingga menjadi kemampuan efektif.

Variabel kinerja yang terdiri dari tujuh indikator, dituangkan dalam delapan item pernyataan yang hasil jawabannya adalah sebagai berikut:

Berdasarkan tabel diatas nampak bahwa pernyataan atau item kesatu $\left(\mathrm{Y}_{1}\right)$ dari variabel kinerja yakni dalam melaksanakan pelayanan, perawat menghormati/menghargai pasien/klien dan keluarganya, maka hasil ini menunjukkan bahwa mayoritas responden menyatakan bahwa perawat di RSSA sudah menghormati atau menghargai pasien atau klien dan keluarganya dalam melaksanakan pelayanannya. Hal ini berarti bahwa para perawat di RSSA telah memiliki sikap yang menghormati dan menghargai hak-hak pasien/klien seperti hak untuk pencegahan bahaya.

Pernyataan atau item kedua $\left(\mathrm{Y}_{2}\right)$ dari variabel kinerja yakni dalam melaksanakan pelayanan, perawat memberikan penjelasan secara benar/ menerapkan informed concent, maka hasil ini menunjukkan bahwa mayoritas responden menyatakan bahwa perawat di RSSA sudah memberikan penjelasan secara benar serta menerapkan informed concent kepada konsumen RS sebelum mereka

Tabel 3: Tanggapan Responden Tentang Kinerja Perawat (Y)

\begin{tabular}{ccccccc}
\hline \multirow{2}{*}{ Pernyataan } & \multicolumn{9}{c}{ Skor } & Total \\
\cline { 2 - 6 } & $\mathbf{5}$ & $\mathbf{4}$ & $\mathbf{3}$ & $\mathbf{2}$ & $\mathbf{1}$ & \\
\hline $1\left(\mathrm{Y}_{1}\right)$ & 40 & 58 & 2 & 0 & 0 & 100 \\
$2\left(\mathrm{Y}_{2}\right)$ & 31 & 66 & 3 & 0 & 0 & 100 \\
$3\left(\mathrm{Y}_{3}\right)$ & 19 & 68 & 13 & 0 & 0 & 100 \\
$4\left(\mathrm{Y}_{4}\right)$ & 32 & 66 & 2 & 0 & 0 & 100 \\
$5\left(\mathrm{Y}_{5}\right)$ & 50 & 46 & 4 & 0 & 0 & 100 \\
$6\left(\mathrm{Y}_{6}\right)$ & 43 & 54 & 3 & 0 & 0 & 100 \\
$7\left(\mathrm{Y}_{7}\right)$ & 39 & 57 & 4 & 0 & 0 & 100 \\
$8\left(\mathrm{Y}_{8}\right)$ & 35 & 60 & 4 & 1 & 0 & 100 \\
\hline
\end{tabular}


melaksanakan kegiatan pelayanannya. Perawat adalah tenaga yang mempunyai kontak paling lama dengan pasien, dituntut untuk dapat menjawab pertanyaan dengan cara yang relevan, tepat, empati dan mudah dimengerti oleh pasien atau klien RS.

Pernyataan atau item ketiga $\left(\mathrm{Y}_{3}\right)$ dari variabel kinerja yakni dalam melaksanakan pelayanan, perawat melibatkan konsep diri dalam menentukan hal terbaik yang bisa dia lakukan untuk semua pasien, maka hasil ini menunjukkan bahwa mayoritas responden menyatakan bahwa perawat di RSSA sudah melibatkan konsep diri dalam menentukan hal terbaik yang bisa dia lakukan untuk semua pasiennya. Pelibatan konsep diri dalam penyelenggaraan pelayanan adalah hak seseorang untuk memilih bagi diri mereka sendiri, apa yang menurut pemikiran dan pertimbangannya merupakan hal yang terbaik.

Pernyataan atau item keempat $\left(\mathrm{Y}_{4}\right)$ dari variabel kinerja yakni dalam menyelesaikan tugas sehari-hari, perawat sudah melakukan hal yang baik dan tidak membahayakan orang lain, maka hasil ini menunjukkan bahwa mayoritas responden menyatakan bahwa perawat di RSSA sudah menyelesaikan tugas sehari-hari dengan baik dan tidak membahayakan orang lain. Hal ini berarti bahwa perawat RSSA sudah melakukan kewajibannya untuk melakukan hal yang baik dan tidak membahayakan orang lain.

Pernyataan kelima $\left(\mathrm{Y}_{5}\right)$ dari variabel kinerja yakni dalam menyelesaikan tugas sehari-hari, perawat tidak pernah dengan sengaja menciderai pasien/klien, maka hasil ini menunjukkan bahwa perawat di RSSA sudah melaksanakan kewajibannya sebagai perawat untuk tidak dengan sengaja menimbulkan kerugian atau cidera. Hal ini berarti bahwa artinya bila ada kecelakaan terhadap pasien/ pelanggan ketika masa perawatan hanyalah karena human eror bukan unsur kesengajaan.

Pernyataan atau item keenam $\left(\mathrm{Y}_{6}\right)$ dari variabel kinerja yakni perawat bisa menjaga rahasia semua informasi tentang pasien/klien yang dia rawat, maka hasil ini menunjukkan bahwa mayoritas responden menyatakan bahwa perawat di RSSA menghargai dan merahasiakan semua informasi tentang pasien/klien yang dirawatnya. Semua informasi yang diberikan kepada tenaga perawatan di RSSA akan dihargai dan tidak disampaikan/ dibagikan kepada pihak lain secara tidak tepat.

Pernyataan atau item ketujuh $\left(\mathrm{Y}_{7}\right)$ dari variabel kinerja yakni perawat bisa berlaku adil dalam transaksi dan pelayanan/perlakuan antar individu pasien/klien, maka hasil ini menunjukkan bahwa mayoritas responden menyatakan bahwa perawat di RSSA sudah berlaku adil dalam transaksi dan pelayanan/perlakuan antar individu pasien/klien. Hal ini berarti bahwa perawat di RSSA sudah memberikan perlakuan yang sama kepada masing-masing pasien/klien sesuai dengan kebutuhannya serta tidak memberikan pelayanan spesial kepada salah satu pasien, namun disamaratakan sesuai prinsip dari keadilan.

Pernyataan atau item kedelapan $\left(\mathrm{Y}_{8}\right)$ dari variabel kinerja yakni perawat bisa setia pada kesepakatan dan tanggung jawab yang telah dibuat sesuai dengan asuhan keperawatan, maka hasil ini menunjukkan bahwa mayoritas responden menyatakan bahwa perawat di RSSA sudah setia pada kesepakatan dan tanggung jawab yang telah dibuat sesuai dengan asuhan keperawatan.

Berdasarikan uji t atau uji parsial, maka diperoleh jawaban hipotesis, yang pertama adalah $\mathrm{H}_{1}$ dengan nilai $\mathrm{t}_{\text {hitung }}=5,437>\mathrm{t}_{\text {tabel }}=1,98 \mathrm{de}$ ngan demikian dapat disimpulkan bahwa pelatihan berpengaruh signifikan terhadap kinerja perawat di RSSA, hipotesis ke dua adalah $\mathrm{H}_{2}$ dengan nilai $\mathrm{t}_{\text {hitung }}=0,382<\mathrm{t}_{\text {tabel }}=1,98$ menyatakan bahwa motivasi tidak berpengaruh signifikan terhadap kinerja perawat di RSSA menggunakan. Sedangkan untuk hipotesis tiga, yaitu $\mathrm{H}_{3}$ yang menyatakan bahwa motivasi mampu memoderasi pengaruh pelatihan dengan kinerja perawat di RSSA di buktikan menggunakan uji selisih mutlak, seperti yang terdapat pada tabel 4 berikut:

Variabel terikat Yyang nilainya diprediksi oleh variabel bebas. Dalam penelitian ini, yang menjadi variabel terikat adalah kinerja perawat di RSSA. Melihat nilai koefisien regresi $\left(b_{1}\right)$ sebesar 1,547. Jika dilihat dari tingkat signifikansinya $<0,05$ yakni sebesar 0,000 , maka variabel pelatihan $\left(X_{1}\right)$ berpengaruh positif dan signifikan terhadap kinerja perawat $(\mathrm{Y})$. Hal ini berarti bahwa variabel pelatihan 
Tabel 4: Hasil Uji Nilai Selisih Mutlak

\begin{tabular}{lccccccc}
\hline \multicolumn{1}{c}{ Variabel } & B (koefisien regresi & Beta & $\mathbf{t}_{\text {hitung }}$ & $\mathbf{t}_{\text {tabel }}$ & Sig & Alpha & Hipotesis \\
\hline Konstanta & 34,036 & - & 73,457 & & 0,000 & & - \\
$\quad \mathrm{X}_{1}$ & 1,547 & 0,481 & 5,437 & 1,98 & 0,000 & 0,05 & Diterima \\
$\quad \mathrm{X}_{2}$ & 0,116 & 0,036 & 0,382 & 1,98 & 0,703 & 0,05 & Ditolak \\
Moderator & 0,484 & 0,132 & 1,393 & 1,98 & 0,167 & 0,05 & Ditolak \\
\hline $\mathrm{N}=100$ & & & $\mathrm{~F}_{\text {hitung }}=11.184$ & & \\
$\mathrm{R}=0,509$ & & & $\mathrm{~F}_{\text {tabel }}=3,09$ & & \\
$R$ Square $=0,259$ & & & Sig F= $=0,000$ & & \\
Adjusted $R$ Square $=0,259$ & & & & & \\
\end{tabular}

mampu mempengaruhi kinerja karyawan sebesar $154,7 \%$ atau berpengaruh positif, artinya jika pelatihan ditingkatkan $1 \%$ saja maka kinerja karyawan akan meningkat sebesar 154,7\%.

Sebaliknya, jika kegiatan pelatihan diturunkan $1 \%$ saja maka kinerja karyawan akan menurun sebesar 154,7\%. Angka ini melebihi 100\% yang bermakna bahwa kegiatan pelatihan sangat mendukung terhadap tingkat kinerja karyawan. Selanjutnya melihat nilai koefisien regresi $\left(b_{2}\right)$ sebesar 0,116 . Karena tingkat signifikan variabel motivasi lebih besar dari 0,05 yakni sebesar 0,703, maka variabel motivasi $\left(\mathrm{X}_{2}\right)$ tidak signifikan terhadap kinerja perawat $(\mathrm{Y})$. selanjutnya koefisien regresi $\left(\mathrm{b}_{3}\right)$ sebesar 0,484. Karena tingkat signifikan dari moderator yakni nilai dari Sig adalah 0,167, maka berarti lebih besar dari taraf signifikan (alpha) sebesar 0,05. $(0,167>0,05)$, sehingga motivasi bukan merupakan variabel moderasi. Sedangkan e yaitu error (variabel lain yang tidak dijelaskan dalam model). Pelatihan merupakan salah satu usaha organisasi yang sengaja dilakukan untuk meningkatkan kinerja. Sesuai dengan pendapat Moekijat (1996:9), bahwa pelatihan harus bisa membantu pegawai menambah pengetahuannya dalam menjalankan tugasnya serta mampu menimbulkan perubahan kebiasaan, sikap, dan informasi yang diterapkan dalam tugas. Berdasarkan interpretasi di atas, menunjukkan bahwa teori tentang pelatihan dapat mempengaruhi kinerja karyawan pada suatu perusahaan adalah benar adanya. Hal ini terbukti dalam penelitian yang dilakukan di RSSA, bahwa pelatihan mampu mempengaruhi kinerja karyawan sebesar 154,7 \%. (tabel 4). Hal ini berarti jika pelatihan ditingkatkan $1 \%$ saja maka kinerja karyawan akan meningkat sebesar $154,7 \%$. Sebaliknya, jika kegiatan pelatihan diturunkan 1\% saja maka kinerja karyawan akan menurun sebesar 154,7\% dengan asumsi variabel bebas lainnya tetap Ceteris Paribus.

Sedangkan motivasi baik sebagai variabel bebas maupun sebagai variabel moderasi, diketahui belum bisa mempengaruhi kinerja perawat di RSSA secara signifikan. Namun jika dibandingkan antara motivasi sebagai variabel bebas dan motivasi sebagai variabel moderasi, sebenarnya kemampuan pengaruhnya terhadap kinerja lebih besar saat berstatus sebagai variabel bebas.

\section{SIMPULAN}

Berdasarkan hasil analisis data dan pengujian hipotesis yang telah dilakukan maka dapat diambil kesimpulan yang pertama, bahwa pelatihan berpengaruh signifikan terhadap kinerja perawat di RSSA. Artinya, pendapat Moekijat, Simamora, Hollenback dan Wright tentang pelatihan yang dapat meningkatkan kinerja karyawan atau pegawai pada perusahaan tertentu adalah terbukti benar dan dapat diterima ketika pendapat tersebut diterapkan di RSSA, kedua yaitu motivasi tidak berpengaruh signifikan terhadap kinerja perawat di RSSA, hal ini menunjukkan bahwa pendapat Abraham Maslow terkait kebutuhan manusia yang diklasifikasikan pada lima hirarkhi kebutuhan yaitu: kebutuhan fisiologis, kebutuhan akan keamanan, 
kebutuhan sosial, kebutuhan esteem, dan kebutuhan untuk aktualisasi diri kurang tepat jika diterapkan di RSSA, sedangkan yang ketiga yaitu motivasi tidak mampu berperan sebagai pemoderat terhadap pengaruh pelatihan terhadap kinerja perawat di RSSA.

Berdasarkan hasil penelitian tersebut, adapun saran - saran yang dapat diberikan yaitu yang pertama bahwa manajemen RSSA mutlak perlu menyusun program yang sistematik untuk pengembangan pegawainya, karena terbukti bahwa pelatihan mampu mempengaruhi kinerja perawat, selanjutnya bagi para manajer RS seyogyanya lebih mampu meyakinkan kepada para karyawan bahwa dengan tercapainya tujuan organisasi, tujuan-tujuan pribadi para karyawan itu akan ikut tercapai pula. Dengan demikian dalam diri para bawahan itu terdapat keyakinan bahwa terdapat sinkronisasi antara tujuan pribadinya dengan tujuan organisasi secara keseluruhan, dan yang terakhir ditujukan pada para calon peneliti pada bidang yang sama, sebaiknya penelitian dilakukan pada tempat pelayanan kesehatan yang berbeda serta memakai teori motivasi lainnya, misalnya Teori "X" dan Teori "Y" Douglas Mc-Gregor, Teori Motivasi-Higiene Frederick Herzberg, Teori ERG Clayton Alderfer, Teori “Tiga Kebutuhan”, atau teori mengenai motivasi yang lainnya sehingga hasilnya bisa dibandingkan, baik persamaan maupun perbedaan terhadap penelitian ini.

\section{DAFTAR PUSTAKA}

Boedihartono (1991). Konsep dan Proses Keperawatan, Jakarta: Dirjen Pelayanan Medik Depkes RI

Depkes R.I. (1999). Pedoman Uraian Tugas Tenaga Keperawatan di Rumah Sakit, Jakarta: Dirjen Yanmed

Depkes R.I. (2009). Modul I, Aplikasi Nilai-Nilai Profesional dalam Praktik Keperawatan, Jakarta: Pusdiklat
Mangkunegara, Anwar Prabu (2000). Manajemen Sumber Daya Manusia Perusahaan, Bandung: Remaja Rosdakarya

Mangkunegara, Anwar Prabu (2005). Evaluasi Kinerja SDM, Bandung: PT. Refika Aditama

Moekijat (1996). Manajemen Personalia dan Sumber Daya Manusia, Bandung:Mandar Maju

Moenir (1995). Latihan dan Pengembangan Sumber Daya Manusia, Bandung: Mandar Maju

Musafir (2009). Pengaruh Pelatihan dan Motivasi terhadap Kinerja Pegawai pelabuhan Indonesia IV Gorontalo, Jurnal Ichsan Gorontalo Volume 4 No.2 Edisi MeiJuli 2009, 2371-2385

Noe Hollenback \& Wright (2003). Human Resources Management, International Edition, Fourth Edition, USA, MC. Grawitill. Lnc

Robbins, Stephen P. (1996). Perilaku Organisasi: Konsep, Kontroversi, dan Aplikasi Edisi Indonesia, Jakarta: PT.Prehalindo

Siagian, Sondang P. (2004). Teori Motivasi dan Implikasinya, Jakarta: PT. Rineka Cipta

Simamora, Henry (2001). Manajemen Sumber Daya Manusia, Yogyakarta: STIE YKPN

Singarimbun (1995). Metode Penelitian Survei, Jakarta: LP3ES

Soetjipto (2007). Pengaruh Faktor Pendidikan, Pelatihan, Motivasi, dan Pengalaman Kerja terhadap Kinerja kepala Desa (Studi pada Kepala Desa di Kecamatan Pakis dan Tumpang Malang) Jurnal Aplikasi Manajemen Volume 5 Nomor I, April 2007, 159-165

Wijaya, Tony (2009). Analisis Data Penelitian Menggunakan SPSS, Yogyakarta: Universitas Atmajaya. 